A 23 気候帯の異なる浄水場ろ過池に生息するユスリカ幼虫数の季節変化 ○平林公男・中本信忠（信州大・織維・忘生）・谷崎樹生（石坦島方胁研究会）

\title{
Seasonal abundance of chironomid larvae in slow sand filter bed
}

\author{
Hirabayashi K., Nakamoto N. and Tanizaki S.
}

緩速乃過式浄水場は河川水をゆっくりとした早さで砂層を通過させ、飲料水を 作る方式で、砂層表面に生物膜ができ、それが浄水に重要な役割を果たしている。 ユスリカ類の幼虫にとって、浄水場のろ過池は、河川や湖沼などの自然の生息場 所と比較して、極めて高い密度で生息可能なすみ場所の一つである。しかし、我 が国においては、これまでに浄水場ろ過池のユスリカ類についての研究報告はほ とんど無く、近年、Hirabayasi et al. (2001)が、万過池周辺におけるユスリカ成虫相を 報告したものがあるだけである。本研究では、内陸性気候带にある上田市染屋浄 水場と亚熱带性気候帯にある石垣浄水場とで月 1 回、試料を採集し、砂層表面の ユスリカ幼虫数を計測した。いずれのろ過池でも春は幼虫の生息密度が低く、夏 に向けて密度が高くなた。また、石垣浄水場の方が、染屋浄水場に比心゙、幼虫密 度が $20,000 匹 / \mathrm{m}^{2}$ 以上に達するまでの期間が短く、これには水温が関倸している ことが示唆された。

\section{A 24 又カカ科に関する残された諸問題} 北岡茂男（柏崎市）

Several remaining problems on the Japanese Ceratoopogonidae (Diptera) Shigeo Kitaoka (Kashiwazaki City)

吸血性の八エ目昆虫で種類が極めて多いヌカカ科には、世界で125属、約6000種が記 録されているにも拘わらず、わが国では Culicoides, Lasiohelea, Leptoconops 以外 の諸属についての研究は、徳永(1972)以降、全く白紙状態に留まっている。

又カカ科の種数の約 $23 \%$ 占める Culicoides の代表的な人吸血種は、古く和名で又

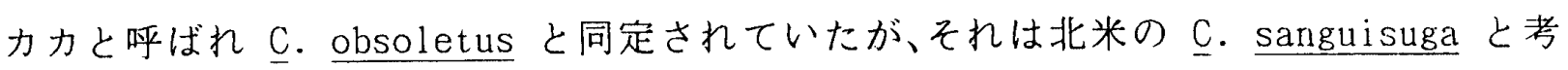
えられる種が優先するが、むしろ $\mathrm{C}$. nupurius など近似種が混在する種群に対する 総称名であると結論され、最終的な解明が待たれる。

Culicoides の種類に関して和田(1999) は78種を挙げたが、その後 C. orientalis, C. hewitti， C. hasegawai， C. nupurius などが記録、或は新種が追加されたと共に、 NEMURO、IWATE, ODA, OGASAWARA, EHIME などの 5 末記載種も存在し、本属の種相の全 容が明らかにされるためには更に多くの時間が必要である。 